\title{
Kualitas Air Sungai pada Berbagai Tipe Penutupan Lahan pada Sub-sub DAS di DAS Latuppa
}

\author{
Fauziyah Abidin ${ }^{1}$, Syamsuddin Millang ${ }^{2}$, Usman Arsyad $^{2}$ \\ ${ }^{1}$ Fakultas Kehutanan, Universitas Hasanuddin, Makassar \\ Email: abidinfauziyah94@gmail.com
}

\begin{abstract}
Water has an important role in life. The use of water in various activities must be based on water quality which is influenced by various aspects, one of it is land cover. This study aims to determine water quality, water quality standards and the effect of land cover on water. This study took samples at six points to determine the physical and chemical quality of water. The results showed that the chemical and physical quality of water in the Latuppa watershed still met water quality standards when there was no rain. Parameters that did not meet when rain occurred in the form of turbidity, TSS, and BOD in the river water of the Latuppa watershed. Water quality of the Siguntu Sub-watershed and the Mangkaluku Subwatershed in the Latuppa River Basin is still relatively good for the use of raw water for drinking water. The water quality in the Latuppa watershed which is covered by forest land (Siguntu Sub-watershed and Mangkaluku Sub-watershed) is better than non-forested (Rantenase Sub-watershed).
\end{abstract}

Key words: Land cover, Water quality, Watershed

DOI : http://dx.doi.org/10.24259/ihm.v11i1.5933

\section{PENDAHULUAN}

Air dalam kehidupan sehari-hari dimanfaatkan terutama untuk air minum, mandi, memasak dan kebutuhan lainnya (Agustiningsih et al., 2012). Pemanfaatan air yang digunakan oleh manusia baik yang bersumber dari air tanah maupun dari sungai harus sesuai dengan standar baku mutu terhadap pemanfaatannya karena kualitas air yang bersumber dari sungai tersebut tidak diketahui dan dapat mengandung zat yang berbahaya bila dikonsumsi langsung. Kualitas air sungai tergantung pada sumber mata airnya dan penutupan lahannya serta aktivitas yang ada pada lahan tersebut. Kualitas air pada daerah berhutan akan berbeda dengan kawasan pertanian serta pemukiman. Hal tersebut disebabkan oleh aktivitas masyarakat yang memanfaatkan lahan. Asdak (2014) menyatakan bahwa terjadinya perubahan kualitas air dikarenakan berkurangnya areal hutan secara meluas serta praktek bercocok tanam yang tidak atau kurang mengindahkan kaidah-kaidah konservasi.

Hasil penelitian oleh Ali et al., (2013), terhadap sifat kimia, fisika, dan biologi air didapatkan bahwa pada kawasan hulu yang berhutan kualitas airnya lebih baik daripada kawasan tengah dan hilir yang penutupan lahannya berbeda dengan di hulu. Hal yang sama juga didapatkan oleh Supangat (2008), bahwa semakin kecil tutupan hutan serta semakin beragamnya jenis penggunaan lahan dapat menyebabkan kondisi kualitas air sungai yang semakin buruk, terutama akibat adanya aktivitas pertanian dan pemukiman. Gorde dan Jadhav (2014), mendapatkan bahwa pada musim hujan kualitas air lebih buruk dibanding musim kemarau karena banyaknya aktivitas yang dilakukan oleh masyarakat terutama aktivitas pertanian serta penggunaan lahan yang beragam. Berdasarkan hal tersebut maka dapat diartikan bahwa jenis penutupan lahan dapat memberikan hasil kualitas air yang berbeda. Demikian halnya pada DAS Latuppa yang memiliki penutupan lahan yang berbeda maka kualitas airnya dapat berbeda pula. Penutupan lahan di DAS Latuppa berdasarkan data dari Dinas Kehutanan dalam Yasir (2015) penutupan lahan yang terdiri atas kebun atau ladang campur semak, semak belukar, hutan sekunder, pertanian lahan basah, tambak, pemukiman, dan hutan mangrove sekunder. 
Daerah Aliran Sungai Latuppa merupakan salah satu DAS yang terdapat di Sulawesi Selatan yang bagian hilirnya berupa kawasan perkotaan yaitu Kota Palopo. DAS Latuppa merupakan sumber air yang penting bagi masyarakat di Kota Palopo dan sekitarnya yang dimanfaatkan untuk berbagai keperluan seperti keperluan rumah tangga, pertanian, peternakan, perikanan, industri, dan sebagainya. Hulu DAS Latuppa merupakan sumber air baku PDAM Mangkaluku yang airnya terdistribusi ke Kota Palopo dan merupakan sumber air bagi dua perusahaan air minum kemasan. DAS Latuppa masuk sebagai salah satu DAS prioritas di Indonesia berdasarkan SK. 328/Menhut-II/2009, sehingga analisis kualitas air sebagai sebuah indikator untuk pengelolaan DAS dan pemanfaatan air sangat diperlukan pada DAS Latuppa.

Pemanfaatan yang terus-menerus oleh penduduk, baik untuk kayu bakar, pemukiman maupun untuk budidaya tanaman palawija dan sayuran pada kawasan hutannya menyebabkan perubahan pada kondisi bio-fisik DAS Latuppa yang kemudian berakibat pada hilangnya fungsi hutan sebagai pengatur dan pengendali sistem tata air (Yasir et al., 2016). Lebih lanjut, Yasir et al (2016), menyatakan bahwa DAS Latuppa memiliki kualitas air yang buruk pada musim hujan, terutama pada kekeruhan air. Isnan (2016) menyatakan bahwa kekeruhan sungai DAS Latuppa mencapai titik tertinggi yaitu 10.374 NTU dalam kurun waktu tiga tahun pada 2013-2015. Hal tersebut didukung oleh data dari Badan Pusat Statistik (2016) mengenai statistik air bersih menunjukkan terjadi peningkatan bahan kimia yang digunakan untuk memperbaiki kualitas air dari $6.520 \mathrm{~kg}$ menjadi $10.590 \mathrm{~kg}$ pada tahun 2013-2015. Pernyataan tersebut mengindikasikan perlunya pengelolaan DAS pada DAS Latuppa untuk menjamin kelestarian air dengan kuantitas dan kualitas air yang baik, sehingga kualitas air pada DAS Latuppa perlu diteliti.

\section{METODE PENELITIAN}

\subsection{Tempat dan Waktu Penelitian}

Penelitian ini dilaksanakan pada Bulan Maret sampai Juni 2018 bertempat di DAS Latuppa yang termasuk dalam wilayah administrasi Kecamatan Mungkajang dan Kecamatan Sendana Kota Palopo. Analisis sampel air dilakukan di Laboratorium Oseanografi Kimia Fakultas IImu Kelautan dan Perikanan Universitas Hasanuddin.

\subsection{Alat dan Bahan}

Alat-alat yang digunakan dalam penelitian ini berupa Global Positioning System (GPS), alat ukur debit Current Meter Improvised Mappangaja, stopwatch, botol air, botol kaca gelap dan terang, pipet tetes dan gelas kimia, meteran, tali rafia, masker, sarung tangan, dan cool box. Bahan-bahan yang digunakan dalam penelitian ini berupa sampel air dari sungai dan es batu.

\subsection{Prosedur Penelitian}


Prosedur penelitian terdiri atas penentuan lokasi pengambilan sampel air, pengambilan data, dan metode analisis parameter kualitas air.

\subsubsection{Penentuan Lokasi}

Penentuan lokasi berdasarkan purposive sampling dengan pertimbangan pengambilan hanya pada sungai utama yang masih dimanfaatkan oleh masyarakat. Pengambilan sampel air pada tiga Sub DAS dengan komposisi penutupan lahan yang berbeda, serta pada sungai utama tempat bertemunya ke tiga sungai tersebut. Penutupan lahan dari analisis citra google earth perekaman Tahun 2018. Peta lokasi pengambilan dan penutupan lahan dapat dilihat pada Gambar 1. Lokasi pengambilan sampel, yaitu:

2.3.1.1. Titik 1: Sub DAS Siguntu yang berada di hulu DAS dengan penutupan lahan berupa hutan sekunder $100 \%$.

2.3.1.2. Titik 2: Outlet Sub DAS Siguntu yang memiliki penutupan lahan hutan sekunder $91,19 \%$ dan pertanian lahan kering campur semak $8,81 \%$.

2.3.1.3. Titik 3: Sub DAS Rantenase dengan penutupan lahan semak belukar $85,32 \%$, pertanian lahan kering campur semak $14,44 \%$, dan pemukiman $0,24 \%$.

2.3.1.4. Titik 4: Sub DAS Mangkaluku dengan penutupan lahan pertanian lahan kering campur semak $74,53 \%$ dan hutan sekunder $25,47 \%$.

2.3.1.5. Titik 5: Di sungai utama yang berjarak $300 \mathrm{~m}$ setelah Sub DAS Mangkaluku.

2.3.1.6. Titik 6: Di sungai utama yang berjarak $2,5 \mathrm{~km}$ dari Titik 5 . 




Gambar 1. Peta Penutupan Lahan dan Lokasi Pengambilan Sampel

\subsubsection{Pengambilan Data}

\subsubsection{Pengukuran Debit Air Sungai}

Debit air sungai dapat diketahui dengan mengukur penampang sungai serta kecepatan aliran air dalam sungai. Pengukuran debit dilakukan pada berbagai kedalaman.

\subsection{Pengukuran Penampang Sungai}

Luas penampang sungai dapat dihitung dengan mengukur lebar penampang horizontal kemudian dikalikan dengan kedalaman sungai. Lebar sungai dapat diketahui dengan cara mengukur penampang basah sungai, yaitu dari tepi sungai yang satu ke tepi sungai lainnya yang masih dilalui oleh air. Kemudian mengukur kedalaman muka air maksimum dengan cara membagi penampang melintang sungai menjadi beberapa bagian pada setiap jarak satu meter. Pada setiap jarak satu meter dilakukan pengukuran kedalaman.

\subsection{Pengukuran Debit Sungai}

Pengukuran debit dilakukan pada beberapa bagian sungai seperti kedua bagian pinggir penampang melintang sungai dan bagian tengah penampang melintang sungai. Pada setiap bagian penampang melintang sungai dilakukan pengukuran pada kedalaman $20 \%, 60 \%$, dan $80 \%$.

\subsubsection{Pengambilan Sampel Air}

Pengambilan sampel pada air sungai diambil dengan cara pengambilan sampel sesaat. Pengambilan sampel dilakukan pada dua keadaan, yaitu pada saat setelah terjadi hujan dan pada saat tidak terjadi hujan kurang lebih satu minggu untuk memastikan bahwa sampel air tersebut tidak 
terpengaruh oleh air hujan. Masing-masing keadaan tersebut dilakukan dengan tiga kali pengulangan. Pengambilan sampel pada bagian tengah sungai serta berada pada setengah kedalaman sungai. Pengambilan air menggunakan botol kemudian dimasukkan ke dalam cool box yang berisi es batu. Sampel kemudian dibawa ke laboratorium dalam kurun waktu kurang dari 24 jam.

\subsubsection{Analisis Parameter Kualitas Air}

Metode yang digunakan untuk analisis parameter kualitas air tertera pada Tabel 1.

Tabel 1. Metode Analisis Parameter Kualitas Air

\begin{tabular}{lcll}
\hline Parameter & Satuan & Metode/Alat analisis & Keterangan \\
\hline Kekeruhan & NTU & Nephelometri & Pengujian di Laboratorium \\
\hline TDS & $\mathrm{mg} / \mathrm{L}$ & TDS meter & Pengujian di Laboratorium \\
\hline TSS & $\mathrm{mg} / \mathrm{L}$ & Gravimetri & Pengujian di Laboratorium \\
\hline Nitrat & $\mathrm{mg} / \mathrm{L}$ & Metode Bruchine & Pengujian di Laboratorium \\
\hline BOD & $\mathrm{mg} / \mathrm{L}$ & Titrasi & Pengujian di Laboratorium \\
\hline
\end{tabular}

\subsection{Analisis Data}

\subsubsection{Analisis Kualitas air}

Hasil pengukuran parameter kualitas air dibandingkan dengan baku mutu air. Penentuan kualitas air di DAS Latuppa disesuaikan berdasarkan kriteria pada Peraturan Pemerintah No. 82 Tahun 2001 tentang Pengelolaan Kualitas Air dan Pengendalian Pencemaran Air dan baku mutu menurut Peraturan Menteri Kesehatan No. 492 Tahun 2010 tentang Persyaratan Kualitas Air Minum.

2.4.2. Hasil analisis sifat kimia dan fisika air pada berbagai penutupan lahan dianalisis dengan Nested Analysis. Perbedaan sifat kimia dan fisika air pada berbagai lokasi dengan Uji Beda Nyata Jujur (BNJ) pada aplikasi SPSS 16.0 for windows.

\section{HASIL DAN PEMBAHASAN}

\subsection{Hasil}


3.1.1. Parameter Kualitas Kimia dan Fisika

Hasil analisis laboratorium parameter kimia dan fisika air sungai DAS Latuppa disajikan pada Tabel 2.

Tabel 2. Hasil Uji Parameter Fisika dan Kimia Air Sungai DAS Latuppa

\begin{tabular}{|c|c|c|c|c|c|c|}
\hline \multirow[b]{2}{*}{ Lokasi } & \multirow[b]{2}{*}{ Keadaan } & \multicolumn{5}{|c|}{ Parameter Uji } \\
\hline & & $\begin{array}{l}\text { Kekeruhan } \\
\text { (NTU) }\end{array}$ & $\begin{array}{c}\text { TSS } \\
(\mathrm{mg} / \mathrm{L})\end{array}$ & $\begin{array}{c}\text { TDS } \\
(\mathrm{mg} / \mathrm{L})\end{array}$ & $\begin{array}{l}\text { Nitrat } \\
(\mathrm{mg} / \mathrm{L})\end{array}$ & $\begin{array}{l}\text { BOD } \\
(\mathrm{mg} / \mathrm{L})\end{array}$ \\
\hline \multirow{2}{*}{1} & Tidak Hujan & 1,48 & 33,01 & 98,10 & 0,16 & 1,05 \\
\hline & Hujan & 9,80 & 46,60 & 29,70 & 0,28 & $\overline{0,98}$ \\
\hline \multirow{2}{*}{2} & Tidak Hujan & 1,67 & 36,89 & 41,70 & 0,16 & 1,18 \\
\hline & Hujan & 4,92 & 34,95 & 27,60 & 0,18 & 1,47 \\
\hline \multirow{2}{*}{3} & Tidak Hujan & 8,04 & 36,89 & 83,90 & 0,22 & 1,21 \\
\hline & Hujan & $1.135,33$ & 176,70 & 27,90 & 0,16 & $\overline{3,17}$ \\
\hline \multirow{2}{*}{4} & Tidak Hujan & 0,71 & 27,18 & 53,10 & 0,19 & 1,05 \\
\hline & Hujan & 62,00 & 54,37 & 43,80 & 0,12 & 1,80 \\
\hline \multirow{2}{*}{5} & Tidak Hujan & 1,10 & 29,13 & 50,90 & 0,15 & 2,35 \\
\hline & Hujan & $1.521,67$ & 203,85 & 33,30 & 0,18 & 1,70 \\
\hline \multirow{2}{*}{6} & Tidak Hujan & 0,49 & 25,24 & 53,50 & 0,17 & 0,59 \\
\hline & Hujan & $1.660,00$ & 231,07 & 31,50 & 0,47 & 2,35 \\
\hline
\end{tabular}

3.1.2. Pengaruh Penutupan Lahan terhadap Parameter Kualitas Air

Pengaruh penutupan lahan terhadap parameter fisika dan kimia air dianalisis menggunakan nested analysis dengan sumber keragaman berasal dari penutupan lahan yang berbeda serta perbedaan kondisi hujan dan tidak hujan pada kondisi penutupan lahan yang sama. Hasil uji Beda Nyata Jujur (BNJ) pada masing-masing parameter fisika dan kimia air sungai tertera pada Tabel 3.

\section{Lokasi}

Uji BNJ Parameter Kualitas Air 


\begin{tabular}{|c|c|c|c|c|c|}
\hline & Kekeruhan (NTU) & TDS (mg/L) & TSS (mg/L) & Nitrat (mg/L) & BOD (mg/L) \\
\hline 1 & $5,64 a$ & $63,90 \mathrm{e}$ & $39,81 \mathrm{~b}$ & $0,22 \mathrm{~d}$ & $1.01 \mathrm{a}$ \\
\hline 2 & $3,29 a$ & $34,65 a$ & $35,92 \mathrm{a}$ & $0,17 \mathrm{~b}$ & $1.32 a b$ \\
\hline 3 & $571,69 \mathrm{c}$ & $55,90 d$ & $106,80 \mathrm{c}$ & $0,19 \mathrm{c}$ & $2.19 \mathrm{c}$ \\
\hline 4 & $31,36 \mathrm{~b}$ & $48,45 \mathrm{c}$ & $40,78 \mathrm{~b}$ & $0,16 a$ & $1.42 a b$ \\
\hline 5 & $761,38 d$ & $42,10 \mathrm{~b}$ & $116,49 d$ & $0,16 \mathrm{~b}$ & $1.47 a b$ \\
\hline 6 & $830,24 \mathrm{e}$ & $42,50 \mathrm{~b}$ & $128,16 \mathrm{e}$ & $0,32 \mathrm{e}$ & $2.02 \mathrm{c}$ \\
\hline
\end{tabular}

$\mathrm{n}$ : Huruf yang sama menyatakan berbeda tidak nyata

\subsection{Pembahasan}

\subsubsection{Kekeruhan}

Kekeruhan air pada DAS Latuppa memiliki nilai terendah 0,49 NTU pada lokasi 6 saat tidak hujan dan tertinggi 1.660 NTU saat hujan pada lokasi yang sama. Tingkat kekeruhan yang tinggi juga terjadi pada lokasi 3 dan 5 jika terjadi hujan, serta lokasi 6 yang tertinggi, namun lebih kecil bila dibandingkan dengan hasil penelitian Isnan (2016) kekeruhan di DAS Latuppa mencapai 10.374 NTU pada tahun 2013.

Penutupan lahan yang memiliki hutan sekunder yang dominan, tingkat kekeruhannya lebih rendah dibanding penutupan lainnya. Lokasi 1 dan 2 yang terletak di Sub DAS Siguntu meningkat tingkat kekeruhannya sebanyak 8,32 kali dan 2,95 kali jika terjadi hujan serta Lokasi 4 yang terletak di Sub DAS Mangkaluku meningkat sebanyak 84,51 kali. Sub DAS Mangkaluku yang memiliki persentase luas hutan yang lebih sedikit dari hutan di Sub DAS Siguntu dapat menjadi penyebab peningkatannya lebih besar. Sub DAS Siguntu dan Sub DAS Mangkaluku masing-masing terdapat penutupan lahan berupa hutan memiliki tingkat kekeruhan yang meningkat sebanyak 19,82 kali, sedangkan di Sub DAS Rantenase yang tidak berhutan meningkat sebanyak 141,21 kali pada saat hujan. Hal tersebut berkaitan dengan adanya erosi yang menyebabkan kekeruhan pada sungai akibat aliran permukaan. Arsyad (2010) menjelaskan bahwa lahan yang penutupannya sedikit vegetasi memiliki erosi yang lebih besar dibanding lahan yang bervegetasi berkayu serta tajuk yang berlapis.

Pada sungai utama setelah pertemuan air dari ke tiga sungai, tingkat kekeruhan sangat tinggi karena merupakan jumlah dari keseluruhan sungai yang ada di atas titik pertemuan (Lokasi 5) dan bertambah di titik selanjutnya (Lokasi 6). Masing-masing penutupan lahan tersebut berbeda nyata pada taraf nyata 95\%. Penutupan lahan berupa hutan sekunder (Lokasi 1) dan hutan sekunder dan pertanian lahan kering (Lokasi 2) menunjukkan tidak berbeda nyata. Hal tersebut berarti nilai kekeruhan pada dua lokasi tersebut tidak jauh berbeda karena masih berada pada sub DAS yang sama, yaitu Sub DAS 
Siguntu sehingga keberadaan hutan sekunder yang persentasenya tinggi dibandingkan PLKCS dapat memiliki pengaruh yang sama terhadap kekeruhan.

Pada penutupan semak belukar memiliki tingkat kekeruhan yang tinggi karena pada lokasi tersebut juga terdapat pertanian walaupun tidak luas. Hal tersebut karena petani di lokasi ini bertanam perilla yang memerlukan lahan yang bebas dari rumput dan tumbuhan lain sehingga ketika terjadi hujan maka ruang kosong antar tanaman akan langsung terkena tetesan hujan yang mengakibatkan erosi. Erosi dapat dipengaruhi faktor iklim dan aktivitas manusia (Arsyad, 2010; Asdak, 2014). Area pertanian perilla tersebut juga terdapat pada kondisi yang curam. Tanaman semusim seharusnya ditanam pada area yang datar untuk menghindari erosi dan kekritisan lahan (Albasri dkk, 2015). Tanah yang tererosi pada area pertanian perilla kemudian terbawa oleh aliran permukaan ke sungai sehingga menambah kekeruhan air. Pengelolaan lahan berpengaruh terhadap erosi yang akhirnya berpengaruh terhadap kualitas air (Asdak, 2014).

Curah hujan yang tinggi merupakan salah satu faktor yang menyebabkan tingkat kekeruhan air menjadi tinggi (Lee dkk, 2016). Erosi dapat disebabkan oleh curah hujan, jenis tanah, kemiringan lereng, dan aktivitas manusia. Isnan (2016) menjelaskan bahwa curah hujan yang tinggi yang terjadi di Kota Palopo menjadi penyebab tingginya aliran permukaan dan erosi, bahkan pada beberapa kondisi curah hujan yang tinggi, menyebabkan banjir di bagian hilir dan tanah longsor di bagian hulu Sungai Latuppa.

\subsubsection{TSS}

Nilai TSS pada DAS Latuppa berkisar antara 25,4 sampai $231,07 \mathrm{mg} /$ liter. Nilai terendah tersebut terjadi pada saat tidak hujan dan nilai tertinggi terjadi pada saat hujan pada lokasi yang sama. Nilai TSS di lokasi 3, 4, 5, dan 6 tidak memenuhi baku mutu yang dipersyaratkan karena nilainya lebih dari $50 \mathrm{mg} / \mathrm{l}$. Nilai TSS tersebut tinggi bila terjadi hujan. Hal tersebut menandakan bahwa kondisi hujan berpengaruh besar terhadap penambahan TSS pada air sungai. Hasil penelitian yang didapatkan sesuai dengan penelitian Marlina, dkk (2017) di Sungai Winongo, Yogyakarta bahwa kondisi hujan menyebabkan TSS dapat melebihi nilai mutu kualitas air. Lebih lanjut, Ahmad (2009) menyatakan bahwa terjadi peningkatan nilai TSS yang lebih besar pada saat musim hujan dibanding pada kondisi normal. Kadar TSS yang tinggi pada saat hujan dapat disebabkan oleh terjadinya erosi yang kemudian masuk ke sungai melalui aliran permukaan.

Tabel 3 menampilkan hasi uji BNJ terhadap TSS yang dapat dijelaskan bahwa terdapat pengaruh nyata di berbagai lokasi kecuali pada lokasi 1 dan lokasi 4. Meskipun demikian, antara lokasi 1, 2, dan 4 masing-masing memiliki nilai TSS yang lebih rendah dibanding lokasi lainnya, sedangkan di lokasi 3 , 5,dan 6 memiliki nilai TSS yang tinggi dan saling berbeda nyata.

Lokasi yang memiliki penutupan lahan berupa hutan sekunder memiliki tingkat TSS lebih rendah dibanding yang tidak berhutan. Hal tersebut serupa dengan tingkat kekeruhan yang telah dibahas di point 3.2.1. Pada lokasi 5 dan 6 sangat wajar bila sangat tinggi pada lokasi tersebut karena merupakan 
akumulasi dari sungai-sungai yang ada di hulu sehingga nilai TSS-nya lebih besar. Pada lokasi 3 yang didominasi semak belukar namun terdapat kegiatan pertanian di dalamnya memiliki tingkat TSS yang lebih tinggi karena adanya erosi tanah yang masuk ke sungai. Lusiana dkk. (2008) menjelaskan bahwa polusi dan kekeruhan air dapat diakibatkan erosi yang disebabkan oleh limpasan permukaan.

Marlina, dkk (2017) mengatakan bahwa TSS berhubungan dengan kekeruhan air yang disebabkan limpasan air dari daratan. Hal ini dapat memicu tingginya nilai TSS di DAS Latuppa. Yasir (2015) mendapatkan bahwa tingkat erosi di DAS Latuppa mencapai 141,29 ton/ha/tahun dan sedimentasi yang mencapai 17,92 ton/ha/tahun. Terjadinya erosi tersebut dapat berpengaruh ke kekeruhan air yang disebabkan meningkatnya TSS.

\subsubsection{TDS}

Nilai TDS di DAS Latuppa berkisar antara 27,60 sampai $98,10 \mathrm{mg} / \mathrm{l}$. Nilai terendah pada lokasi dua pada saat hujan dan nilai tertinggi pada lokasi satu pada saat tidak hujan. Nilai TDS mengalami penurunan jika terjadi hujan berbeda dengan parameter kualitas air lainnya yang cenderung meningkat jika terjadi hujan. Hal tersebut berarti terjadi pengenceran pada saat debit bertambah jika terjadi hujan sehingga beban pencemaran menurun. Pribadi (2005) menjelaskan bahwa jika debit air bertambah maka konsentrasi beban pencemaran berkurang karena terjadi pengenceran bahan pencemar oleh volume air yang besar.

Besarnya nilai TDS saat tidak hujan dibandingkan tidak hujan kemungkinan disebabkan karena pada saat tidak hujan, air mengalir pada celah-celah batuan, air mengalir dari dalam tanah yang dapat memicu terbawanya padatan masuk ke sungai sedangkan jika terjadi hujan, air yang masuk ke sungai lebih banyak berasal dari aliran permukaan sehingga yang terbawa hanya zat padat yang berasal dari daratan. Effendi (2003) menjelaskan bahwa nilai TDS tinggi pada bagian hulu karena adanya bahan organik yang berupa ion-ion yang berasal dari pelapukan batuan, serasah, renik, batuan dan tanah. Ismangil dan Hanudin (2005) dan Aini, dkk (2016) menjelaskan bahwa batuan mengandung kumpulan mineral. Mineral yang terdapat di air sungai dapat menjadi sumber TDS akibat adanya pelapukan batuan.

Tabel 3 menunjukkan pengaruh penutupan lahan terhadap nilai padatan terlarut. Penutupan hutan sekunder pada lokasi 1 yang paling besar dikarenakan banyaknya ion-ion yang berasal dari pelapukan batuan, serasah, dan tanah. Batuan mengandung kumpulan mineral yang dapat melapuk karena air dan asam organik (Ismangil dan Hanudin, 2005).

Lokasi 5 dan 6 yang memiliki nilai TDS yang kecil namun tidak berbeda nyata di kedua lokasi tersebut karena pentupan lahan di sekitar lokasi tersebut berupa pemukiman yang sedikit vegetasi di sekitarnya. Salsawila, dkk (2016) menyatakan bahwa semakin berkurangnya penutupan lahan berupa hutan dan vegetasi menyebabkan ion-ion berkurang sehingga nilai TDS semakin kecil.

\subsubsection{Nitrat}


Kandungan nitrat dalam air sungai di DAS Latuppa berkisar antara 0,12 - 0,47 mg/liter. Nilai maksimun terdapat pada lokasi enam dan nilai minimum terdapat pada lokasi empat pada keadaan hujan. Kadar nitrat di semua lokasi masih memenuhi baku mutu karena masih di bawah $10 \mathrm{mg} /$ liter sehingga dari air sungai di semua lokasi masih aman kadar nitratnya meskipun kandungan nitrat cenderung bertambah jika terjadi hujan. Kadar nitrat yang lebih dari $5 \mathrm{mg} / \mathrm{l}$ mengindikasikan telah terjadi pencemaran (Tatangindatu dkk., 2013). Sungai yang mengandung nitrat yang tinggi sangat berbahaya pada kesehatan manusia dan hewan (Romano dan Zeng, 2007 dalam Al-Badaii dkk. 2013). Kandungan nitrat yang tinggi saat hujan disebabkan karena adanya aliran permukaan yang membawa nitrat dari darat ke sungai. Aktivitas manusia dalam penggunaan pupuk dan pestisida yang mengandung nitrogen dapat berdampak pada ekosistem sungai sehingga mengurangi kualitas air (Hu, 2018).

Hasil uji BNJ terhadap kandungan nitrat dalam air sungai pada berbagai penutupan lahan menunjukkan terdapat perbedaan nyata. Perbedaan tidak nyata hanya terdapat pada Lokasi 2 dan Lokasi 5 yang memiliki nilai nitrat yang hampir sama. Perbedaan paling nyata antara Lokasi 4 dan Lokasi 6. Lokasi 4 yang didominasi PLKCS memiliki nilai nitrat yang paling kecil sedangkan Lokasi 6 yang paling tinggi. Lokasi 6 yang paling tinggi dapat dikarenakan beragamnya aktivitas yang ada di atasnya karena merupakan sungai utama. Lokasi 5 yang merupakan titik gabungan sungai memiliki nilai yang lebih rendah dibandingkan lokasi 6 kemungkinan karena terdapat pengendapan atau sedimentasi selama terjadi aliran dari anak sungai ke titik tersebut. Kadar nitrat dalam air dapat dipengaruhi oleh sedimen (Patty, 2015; Patty dkk, 2015).

Pada penutupan yang terdapat hutan sekunder lebih tinggi dibanding yang lainnya kemungkinan nitrat tersebut berasal dari batuan induk serta dari tanah. Kandungan nitrat terdapat di tanah karena adanya peristiwa fiksasi nitrogen menjadi nitrat oleh vegetasi yang ada di dalam penutupan lahan. Kasno dkk. (2006) menyatakan bahwa nitar merupakan unsur hara makro yang terdapat dalam tanah yang sangat dibutuhkan oleh tumbuhan. Kandungan nitrat dalam tanah dapat masuk ke sungai oleh aliran permukaan. Hu (2018) menjelaskan bahwa kualitas air dapat menurun akibat adanya nitrogen yang berasal dari aktivitas manusia dalam pertanian.

\subsubsection{BOD}

BOD merupakan kebutuhan oksigen biologis oleh makhluk hidup di dalam air (Situmorang, 2017). Semakin kecil BOD berarti kualitas air semakin baik karena sedikitnya kebutuhan oksigen oleh mikroorganisme di dalam air untuk menguraikan limbah. BOD air sungai DAS Latuppa berkisar antara 0,59 sampai $3,17 \mathrm{mg} /$ liter, nilai terendah terdapat pada lokasi 6 dan tertinggi pada lokasi 3. Parameter BOD di DAS Latuppa tidak memenuhi baku mutu pada lokasi 3, 5, dan 6 berarti nilainya lebih dari 2 $\mathrm{mg} / \mathrm{liter}$.

Tabel 3 menunjukkan hasi uji BNJ yang dapat menjelaskan bahwa terdapat pengaruh terhadap BOD oleh penutupan lahan di berbagai lokasi namun tidak semua berbeda nyata. Pada lokasi 1 yang 
memiliki BOD terendah karena merupakan hutan sekunder sehingga tidak banyak limbah organik yang harus diuraikan, begitu pula pada lokasi 2, 4, dan 6, yang juga memiliki penutupan lahan berupa hutan sekunder dan PLKCS.

Lokasi 3 dan 5 yang memiliki nilai BOD tertinggi tidak berbeda nyata dikarenakan penutupan yang ada di lokasi 3 juga terdapat pemukiman, pertanian, ternak serta tempat wisata sehingga lebih banyak limbah dibanding lokasi lainnya. Tatangindatu dkk (2013) menjelaskan bahwa sisa limbah makanan maupun pakan serta kotoran ternak dapat meningkatkan kebutuhan oksigen untuk mengurai bahan organik tersebut sehingga BOD meningkat. Lokasi 5 yang merupakan tempat bertemunya air sungai juga memiliki nilai BOD yang tinggi walau tidak terjadi hujan, hal tersebut dapat terjadi karena di lokasi tersebut merupakan tempat wisata yaitu Sungai Jodoh yang banyak dikunjungi oleh wisatawan sehingga sisa-sisa aktivitas berupa sisa makanan dapat masuk ke sungai meski tidak terjadi hujan. Sisa-sisa makanan dapat dikategorikan limbah sehingga dibutuhkan oksigen yang lebih banyak untuk menstabilkan limbah tersebut (Herlambang, 2006 dalam Sulistyorini, dkk., 2016). Lokasi 6 tidak tinggi dapat dikarenakan lokasi tersebut jauh dari pemukiman yang membuang limbah langsung ke sungai serta lokasi tersebut tidak digunakan untuk wisata seperti lokasi 5 dan lokasi 3.

\subsubsection{Peruntukan Air}

Peruntukan air baku air minum atau peruntukan kelas 1 terdapat pada lokasi 1, 2, dan 4. Kualitas air yang buruk untuk peruntukan kelas 1 yaitu pada lokasi tiga, lima, dan enam dengan parameter yang tidak memuhi baku mutu, yaitu kekeruhan, TSS, dan BOD. Terjadinya hujan dapat membuat kualitas air menurun akibat limpasan permukaan bukan hanya berdampak pada kekeruhan dan TSS, namun juga BOD. Limpasan permukaan dapat membawa limbah organik yang terdapat pada permukaan tanah masuk ke dalam sungai sehingga dibutuhkan lebih banyak oksigen oleh mikroorganisme untuk mengurai limbah tersebut. Daud (2011) menyatakan bahwa air hujan dapat membawa sisa-sisa limbah pertanian dan makanan ternak maupun aktivitas manusia lainnya ke dalam sungai yang dapat berpengaruh pada mikroorganisme di dalam air.

Kualitas air DAS Latuppa berdasarkan analisis pada enam lokasi didapatkan tiga lokasi yang dapat memenuhi untuk peruntukan kelas satu. Namun, ke tiga lokasi tersebut tidak semuanya dapat diperuntukkan menjadi sumber air baku air minum. Hal tersebut dikarenakan tidak semuanya berasal dari mata air langsung. Lokasi 1 dan 2 berada pada sub DAS yang sama sehingga dipilih salah satu jika akan digunakan sebagai air baku air minum sehingga lebih disarankan untuk lokasi 1 karena tidak ada aktivitas pertanian yang sewaktu-waktu dapat memberikan dampak terhadap air sungai terutama jika terjadi hujan yang menyebabkan air mengalir langsung ke sungai melalui limpasan permukaan. UNESCO (1996) mendapatkan bahwa selain limbah industri, sumber utama pencemaran air berasal dari kegiatan pertanian. 


\section{KESIMPULAN}

Kualitas kimia dan fisika air pada DAS Latuppa masih memenuhi standar kualitas air ketika tidak terjadi hujan. Kualitas air Sub DAS Siguntu dan Sub DAS Mangkaluku pada DAS Latuppa masih tergolong baik untuk penggunaan air baku air minum. Kualitas air pada DAS Latuppa yang berpenutupan lahan berupa hutan (Sub DAS Siguntu dan Sub DAS Mangkaluku) lebih baik dibanding yang tidak berhutan (Sub DAS Rantenase).

\section{DAFTAR PUSTAKA}

Agustiningsih, D., Sasongko, S.B., dan Sudarno. 2012. Analisis Kualitas Air dan Strategi Pengendalian Pencemaran Air Sungai Blukar Kabupaten Kendal. Jurnal PRESIPITASI Vol. 9 No.2 September 2012, ISSN 1907-187X.

Ahmad, R.Z. 2009. Cemaran Kapang pada Pakan dan Pengendaliannya. Jurnal Litbang Pertanian. Volume 28 (1), 2009. Hal : 15-22.

Aini, L.N., Mulyono, Hanudin, E. 2016. Mineral Mudah Lapuk Material Piroklastik Merapi dan Potensi Keharaannya Bagi Tanaman. Planta Tropika Journal of Agro Science Vol. 4 No. 2/Agustus 2016.

Albasri, Paembonan, S.A., Millang, S., dan Ma'ruf, A. 2015. Desain Agroforestri pada Lahan Kritis di Desa Kayu Loe, Kecamatan Bantaeng, Kabupaten Bantaeng. Jurnal Ecogreen. Volume 1 No. 1, April 2015. ISSN: 2407-9049.

Ali, A., Soemarno, dan Purnomo, M. 2013. Kajian Kualitas Air dan Status Mutu Air Sungai Metro di Kecamatan Sukun Kota Malang. Jurnal Bumi Lestari, Volume 13 No. 2, Agustus 2013. Halaman 265-274.

Al-Badaii, F., Shuhaimi-Othman, M., dan Gasim, M.B. 2013. Water Quality Assessment of the Semenyih River, Selangor, Malaysia. Journal of Chemistry. Volume 2013, Article ID 871056, 10 pages. http://dx.doi.org/10.1155/2013/871056.

Arsyad, U. 2010. Analisis Erosi pada Berbagai Tipe Penggunaan Lahan dan Kemiringan Lereng di Daerah Aliran Sungai Jeneberang Hulu. Disertasi. Universitas Hasanuddin. Makassar.

Asdak, C. 2014. Hidrologi dan Pengelolaan Daerah Aliran Sungai. Gadjah Mada University Press. Yogyakarta. ISBN: 979-420-737-3.

Badan Pusat Statistik. 2016. Statistik Air Bersih Kota Palopo 2016. BPS Kota Palopo. Katalog: 11020001.7373.031.

Daud, A. 2011. Analisis Kualitas Lingkungan. Penerbit Ombak, Yogyakarta. ISBN: 978-602-8335-80-5. 
Effendi, H. 2003. Telaah Kualitas Air: Bagi Pengelolaan Sumber Daya Alam dan Lingkungan Perairan. Penerbit Kanisius, Yogyakarta. ISBN: 978-979-21-0613-8

Gorde, S.P. dan Jadhav, M.V. 2013. Assessment of Water Quality Parameters: A Review. International Journal of Engineering Research and Applications. Vol. 3, Issue 6, Nov-Dec 2013, pp.2029-2035. ISSN: 2248-9622.

Hu, J. 2018. Human Alteration of the Nitrogen Cycle and Its Impact on the Environment. IOP Conference Series: Earth and Environmental Science 178 (2018) 012030. Doi:10.1088/17551315/178/1/012030.

Ismangil dan Hanudin, E. 2005. Degradasi Mineral Batuan oleh Asam-asam Organik. Jurnal IImu Tanah dan Lingkungan Vol. 5 (1). P: 1-17.

Isnan, W. 2016. Kajian Tingkat Kekeruhan Sungai Latuppa Sebagai Sumber Air Bersih Kota Palopo. Jurnal Info Teknis EBONI Vol. 13 No. 2, Desember 2016 : 131 - 138.

Kasno, A., Setyorini, D., dan Tuberkih, E. 2006. Pengaruh Pemupukan Fosfat terhadap Produktivitas Tanah Inceptisol dan Ultisol. Jurnal IImu-Imu Pertanian Indonesia, Volume 8, No. 2, 2006 : 91-98. ISSn : 1411-0067.

Lee, C.S., Lee, Y.C. dan Chiang, H.M. 2016. Abrupt state change of river water quality (turbidity): Effect of extreme rainfalls and typhoons. Science of the Total Environment: 557-558 (2016) 91-101. http://dx.doi.org/10.1016/j.scitotenv.2016.02.213.

Lusiana, B., Widodo, R., Mulyoutami, E., Nugroho, D.A., dan Noordwijk, M.v. 2008. Kajian Kondisi Hidrologis DAS Kapuas Hulu, Kabupaten Kapuas Hulu, Kalimantan Barat. Working Paper No. 60. World Agroforestry Centre. Bogor, Indonesia.

Marlina, N., Hudori, dan Hafidh, R. 2017. Pengaruh Kekasaran Saluran dan Suhu Air Sungai pada Parameter Kualitas Air COD, TSS di Sungai Winongo Menggunakan Software QUAL2KW. Jurnal Sains dan Teknologi Lingkungan. Volume 9, Nomor 2, Juni 2017 : 122 - 133. ISSN : 2085 - 1227.

Menteri Kesehatan Republik Indonesia. 2010. Peraturan Menteri Kesehatan Republik Indonesia Nomor 492/MENKES/PER/IV/2010 tentang Persyaratan Kualitas Air Minum. Jakarta.

Patty, S, I. 2015. Karakteristik Fosfat, Nitrat, dan Oksigen Terlarut di Perairan Selat Lembeh, Sulawesi Utara. Jurnal Pesisir dan Laut Tropis. Volume 2 Nomor 1 Tahun 2015.

Patty, S.I., Arfah, H. dan Abdul, M.S. 2015. Zat Hara (Fosfat, Nitrat), Oksigen Terlarut dan pH Kaitannya dengan Kesuburan di Perairan Jikumerasa, Pulau Buru. Jurnal Pesisir dan Laut Tropis. Volume 1 Nomor 1 Tahun 2015.

Pemerintah Republik Indonesia. 2001. Peraturan Pemerintah Nomor 82 Tahun 2001 tentang Pengelolaan Kualitas Air dan Pengendalian Pencemaran Air. Jakarta.

Pribadi, M.A. 2005. Evaluasi Kualitas Air Sungai Way Sulan Kecil Kabupaten Lampung Selatan. Fakultas Kehutanan. IPB. Bogor.

Salsawila, H., Arsyad, U., dan Putranto, B. 2016. Kualitas Air Sungai Rakikang Kabupaten Gowa. Fakultas Kehutanan. Universitas Hasanuddin.

Situmorang, M. 2017. Kimia Lingkungan. Rajawali Pers. Depok. ISBN: 978-602-425-165-9. 
Sulistyorini, I.S., Edwin, M., dan Arung, A.S. 2016. Analisis Kualitas Air pada Sumber Mata Air di Kecamatan Karangan dan Kaliorang Kabupaten Kutai Timur. Jurnal Hutan Tropis Volume 4 No.1 Edisi Maret 2016. ISSN: 2337-7771.

Supangat, A.B. 2008. Pengaruh Berbagai Penggunaan Lahan Terhadap Kualitas Air Sungai di Kawasan Hutan Pinus di Gombong, Kebumen, Jawa Tengah. Jurnal Penelitian Hutan dan Konservasi Alam. Volume. V No. $3: 267-276$

Tatangindatu, F., Kalesaran, O., dan Rompas, R. 2013. Studi Parameter Fisika Kimia Air pada Areal Budidaya Ikan di Danau Tondano, Desa Paleloan, Kabupaten Minahasa. Jurnal Budidaya Perairan Mei 2013. Volume 1, No. $2: 8-19$.

United Nations Educational, Scientific and Cultural Organization. 1996. Water Quality Assessments - A Guide to Use of Biota, Sediments and Water in Environmental Monitoring - Second Edition. Published on behalf of WHO by F \& FN Spon. ISBN: 0419215905 (HB) 0419216006 (PB).

Yasir, J.R. 2015. Analisis Pembayaran Jasa Lingkungan Air Bersih di Hulu DAS Latuppa Kota Palopo. Tesis. Institut Pertanian Bogor. Bogor.

Yasir, J.R., Syaukat, Y. dan Ekayani, M. 2016. Analisis Manajemen Kelembagaan untuk Penerapan Mekanisme Pembayaran Jasa Lingkungan Air Bersih di Hulu DAS Latuppa Kota Palopo. Jurnal Aplikasi Manajemen, Volume 14, No. 1, Maret 2016. ISSN: 1693-5241. 